\title{
Waist circumference: a better index of fat location than WHR for predicting lipid profile in overweight/ obese Iranian women
}

T. Shahraki, ${ }^{1}$ M. Shahraki ${ }^{2}$ and M. Roudbari ${ }^{3}$

$$
\begin{aligned}
& \text { محيط الخصر: منسب لتوضع الشحم أفضل من نسبة الورك إلى الخصر للتنبؤ بنمط الشحوم في الإيرانيات البدينات }
\end{aligned}
$$

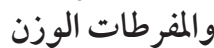

$$
\begin{aligned}
& \text { توران شهركي، منصور شهركي، مسعود رودباري }
\end{aligned}
$$

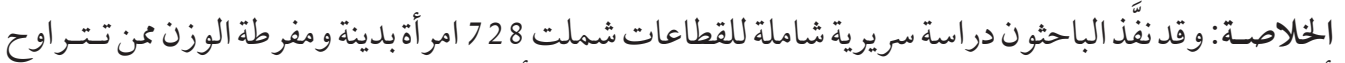

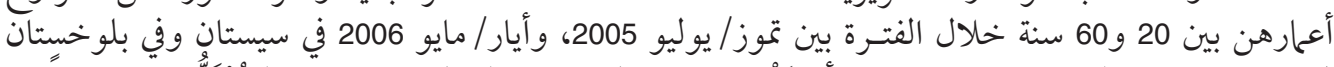

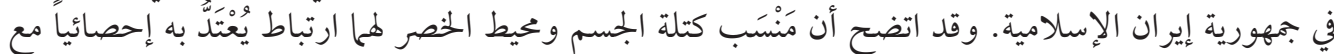

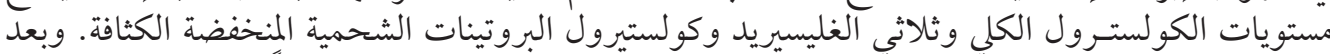

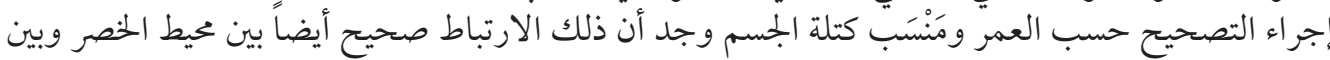

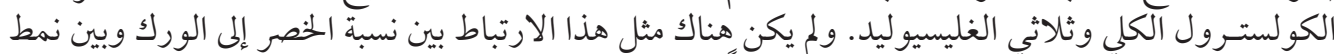

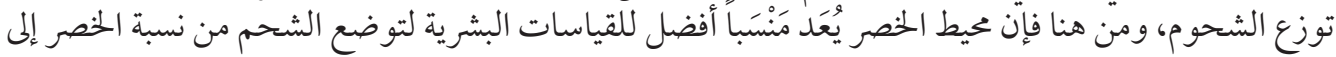

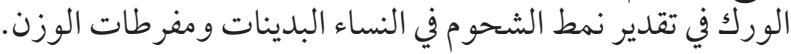

ABSTRACT We carried out a clinical cross-sectional study on 728 overweight and obese women aged 20-60 years during July 2005-May 2006 in Sistan and Baluchestan, Islamic Republic of Iran. Body mass index (BMI) and waist circumference (WC) showed significant correlation with total cholesterol (TC), triglycerides (TG) and low-density lipoprotein cholesterol. After adjustment for age and BMI, this was also true for WC with TC and TG. There was no such correlation between waist-to-hip ratio (WHR) and lipid profile. Hence, WC was a better anthropometric index of fat location than WHR to estimate lipid profile in overweight and obese adult women.

Tour de taille : un meilleur indice de localisation de la graisse que le rapport tour de taille/tour de hanches (RTH) pour la prédiction du profil lipidique chez les Iraniennes en surpoids ou obèses RÉSUMÉ II est essentiel de définir un meilleur indice anthropométrique de localisation de la graisse pour prédire le profil lipidique de telle ou telle population. Nous avons réalisé une étude clinique transversale sur 728 femmes en surpoids et obèses âgées de 20 à 60 ans, entre juillet 2005 et mai 2006, dans la province de Sistan-Balouchestan (République islamique d'Iran). L'indice de masse corporelle (IMC) et le tour de taille présentaient une corrélation significative avec le cholestérol total (CT), les triglycérides (TG) et le cholestérol LDL. Après ajustement en fonction de l'âge et de l'IMC, cette corrélation existait également entre le tour de taille d'une part, et le CT et les TG d'autre part. Elle n'existait pas entre le rapport tour de taille/tour de hanches (RTH) et le profil lipidique. Le tour de taille est donc un indice anthropométrique de la localisation de la graisse permettant d'estimer, de façon plus juste que le RTH, le profil lipidique des femmes adultes en surpoids et obèses.

${ }^{1}$ Department of Paediatrics; ${ }^{2}$ Department of Nutrition \& Research Centre for Child and Adolescent Health, Faculty of Medicine, Zahedan University of Medical Sciences, Zahedan, Islamic Republic of Iran (Correspondence to M. Shahraki: M_shahraki2002@yahoo.com).

${ }^{3}$ Department of Statistics \& Mathematics, School of Management and Medical Information, Iran University of Medical Sciences, Tehran Islamic Republic of Iran.

Received: 25/09/06; accepted: 13/12/06

المجلة الصحية لشرق المتوسط، منظمة الصحة العالمية، المجلد الخنامس عشر، العدد ع، 9 +. 


\section{Introduction}

Nowadays, obesity is not only one of the major causes of life-threatening disease in western societies but also it has become one of the most important health problems in developing countries, including south-east Asia $[1,2]$. The effects of obesity on health, such as diabetes, cardiovascular disease, hypertension, disease of the gallbladder and dyslipidaemia are well recognized [3]. Anthropometric measurements have been used for interpretation of some kinds of obesity: generalized obesity is measured by body mass index (BMI); abdominal obesity, which is closely associated with intraabdominal fat, is measured either by waist circumference (WC) or waist-to-hip ratio (WHR) [4].

Some studies have indicated that WC may be a better reflection of the accumulation of intra-abdominal or visceral fat than WHR [5]. Also, more evidence indicates that WC coupled with BMI predicts cardiovascular disease risk factors better than BMI alone [6]. Other studies have shown that WHR and WC, markers of central adiposity, were more predictive of cardiovascular disease risk factors than BMI, a marker of general obesity $[4,7,8]$.

There is much controversy about the best anthropometric index; this may be explained in part by differences in body composition and fat distribution in different racial groups [9,10], age groups [11] and sexes [12]: according to the literature, obesity is more prevalent among women than among men $[13,14]$. For this reason we evaluated the interrelationship of anthropometric indices for general and central obesity, and the relationship of these indices with the lipid profile in women as the aim of this study.

It should be noted that, in order to evaluate the association of markers of fat loca- tion with lipid profile, analysis should be adjusted for overall adiposity. Therefore, a second aim of our study was to determine the effectiveness of WC and WHR (after adjustment for age and general obesity) for predicting lipid profile and to establish which is a better anthropometric index of fat location.

\section{Methods}

\section{Participants and geographical area}

This cross-sectional study was carried from July 2005 to May 2006 on women in Sistan and Baluchestan who had been referred to either of the 2 nutrition clinics in Zahedan, a city in the centre of the province, which is situated in the south-east of Iran, bordering Pakistan.

A total of 1224 women were referred during the study period. Exclusion criteria were: age below 20 years, those with BMI $\leq 24.9$ or $\geq 40 \mathrm{~kg} / \mathrm{m}^{2}$; and those having dietary treatment for blood lipids and weight loss in the previous 2 months. Pregnant women were also excluded. Applying these criteria, 728 overweight and obese women were eligible to participate in the study. All participants gave their informed consent before recruitment into the study.

\section{Measurements}

All anthropometric measurements were made by trained staff in accordance with WHO standards during clinic visits [15]. Height was measured to the nearest $0.5 \mathrm{~cm}$ with the participant standing without shoes, heels together and head in the horizontal plane. Body weight was measured to the nearest $0.1 \mathrm{~kg}$ using a SECA scale. All measurements of circumference (waist and hip girth) were taken to the nearest $0.5 \mathrm{~cm}$. WC was measured midway between lower rib margin and the iliac crest in the hori- 
zontal plane. Hip-circumference (HC) was measured at the point yielding the maximum circumference over the buttocks. BMI was calculated as weight $(\mathrm{kg})$ divided by the square of the height $\left(\mathrm{m}^{2}\right)$ and WHR was calculated as $\mathrm{WC}(\mathrm{cm})$ divided by $\mathrm{HC}(\mathrm{cm})$.

\section{Blood lipids}

For determining serum blood lipids, a blood sample was drawn between 07:00 and 08:00 into Vacutainer tubes after a 12-hour overnight fast. The samples were taken in a sitting position and centrifuged within $30-45$ minutes of collection. All serum lipid analysis was done at Zahedan Blood Transfusion Laboratory 1 hour after collection. The analysis of samples was performed using the Alcyon Abbott 300 (Abbott, Illinois, United States of America). Total cholesterol (TC) and triglycerides (TG) were assayed using enzymatic colorimetric tests with cholesterol esterase, cholesterol oxidase and glycerol phosphate oxidase (Total cholesterol and triglycerides kits, Pars Azmon Inc., Tehran). High-density lipoprotein cholesterol (HDL-C) was measured after precipitation of the apolipoprotein B-containing lipoproteins with phosphotungstic acid. Low-density lipoprotein cholesterol (LDL-C) was calculated according to the Friedewald equation [16].

\section{Statistical analysis}

All statistical analysis was performed using SPSS software. Pearson correlation coefficient $(r)$ was used to measure the degree of association between anthropometric indices and lipid profile. Partial Pearson correlation coefficient was used for determining the relationship between WC and WHR and lipid profile after adjustment for age and BMI. The $z$-test for Fisher's zeta transformation was used to determine any significant difference between the 2 coefficients. $P<0.05$ was considered statistically significant.

\section{Results}

The characteristics of the study subject are presented in Table 1. The mean age of the women was 32 [standard deviation (SD) 9] years. The mean values for BMI, WHR and WC were 32.0 (SD 3.5) kg/m², 0.89 (SD 0.13 ) and 99.8 (SD 12.0) $\mathrm{cm}$ respectively. Although the participants in our study were overweight and obese women, the mean values for all of the blood lipids were in the normal range (Table 1).

The interrelations between anthropometric indices and their correlation with lipid profile are shown in Table 2. There was a positive significant correlation between BMI and age $(r=0.17 ; P<0.001)$, WHR $(r=0.11 ; P=0.003)$ and WC $(r$ $=0.49 ; P<0.001)$. For WC, the correlation was generally of the same order of magnitude for age and WHR. There was no significant correlation between WHR and age $(r=0.04 ; P=0.2)$. The correlation between BMI, WHR and WC with lipid profile is also shown in Table 2. The Pearson correlation coefficient revealed that BMI and WC indices showed statistically significant positive correlation with TC,

\begin{tabular}{|c|c|c|c|}
\hline Characteristic & Mean & SD & $95 \% \mathrm{Cl}$ \\
\hline Age (years) & 32 & 9 & $31-33$ \\
\hline BMI $\left(\mathrm{kg} / \mathrm{m}^{2}\right)$ & 32.0 & 3.5 & $31.0-32.0$ \\
\hline WHR & 0.89 & 0.13 & $0.88-0.91$ \\
\hline WC (cm) & 99.8 & 12.0 & $98.0-101.0$ \\
\hline $\mathrm{TC}(\mathrm{mg} / \mathrm{dL})$ & 192 & 46 & $186-197$ \\
\hline $\mathrm{TG}(\mathrm{mg} / \mathrm{dL})$ & 134 & 72 & $126-143$ \\
\hline LDL-C (mg/dL) & 119 & 36 & $114-123$ \\
\hline $\mathrm{HDL}-\mathrm{C}(\mathrm{mg} / \mathrm{dL})$ & 48 & 8 & $47-49$ \\
\hline
\end{tabular}

$S D=$ standard deviation; $\mathrm{Cl}=$ confidence interval; $B M I=$ body mass index; $W H R=$ waist-to-hip ratio; $W C=$ waist circumference; $T C=$ total cholesterol; $T G=$ triglycerides; $H D L-C=$ high-density lipoprotein cholesterol; $L D L-C=$ low-density lipoprotein cholesterol. 


\begin{tabular}{|c|c|c|c|c|c|c|}
\hline \multirow[t]{2}{*}{ Variable } & \multicolumn{2}{|c|}{ BMI } & \multicolumn{2}{|c|}{ WHR } & \multicolumn{2}{|c|}{ WC } \\
\hline & $r$ & P-value & $r$ & P-value & $r$ & P-value \\
\hline Age & 0.17 & $<0.001$ & 0.04 & 0.2 & 0.18 & $<0.001$ \\
\hline WHR & 0.11 & 0.003 & - & - & 0.3 & $<0.001$ \\
\hline WC & 0.49 & $<0.001$ & 0.3 & $<0.001$ & - & - \\
\hline TC (mg/dL) & 0.17 & $<0.001$ & $0.05^{*}$ & 0.2 & $0.16^{*}$ & $<0.001$ \\
\hline $\mathrm{TG}(\mathrm{mg} / \mathrm{dL})$ & 0.17 & $<0.001$ & $0.05^{\star}$ & 0.2 & $0.18^{*}$ & $<0.001$ \\
\hline $\mathrm{HDL}-\mathrm{C}(\mathrm{mg} / \mathrm{dL})$ & 0.05 & 0.17 & 0.06 & 0.1 & -0.004 & 0.92 \\
\hline LDL-C (mg/dL) & 0.11 & 0.003 & $0.03^{a}$ & 0.4 & $0.11^{a}$ & 0.004 \\
\hline \multicolumn{7}{|c|}{$\begin{array}{l}{ }^{*} \text { Difference between the } 2 \text { coefficients significant }(\mathrm{P}<0.05) \text { with } z \text {-test for Fisher's } \\
\text { zeta transformation. } \\
{ }^{a} \text { Difference between the } 2 \text { coefficients not significant }(\mathrm{P} \geq 0.05) \text { with } z \text {-test for Fisher's } \\
\text { zeta transformation. } \\
B M I=\text { body mass index; } W H R=\text { waist-to-hip ratio; } W C=\text { waist circumference; } T C=\text { total } \\
\text { cholesterol; } T G=\text { triglycerides; } H D L-C=\text { high-density lipoprotein cholesterol; } L D L-C \\
=\text { low-density lipoprotein cholesterol. }\end{array}$} \\
\hline
\end{tabular}

TG and LDL-C. A test of significance for the difference between the 2 coefficients was done using the $z$-test for Fisher's zeta transformation. The coefficients of WC with TC and TG were significantly greater $(P<0.05)$ than the coefficients of WHR with TC and TG. Although the correlation coefficient of WC with LDL was greater than the correlation coefficient of WHR with LDL (0.11 vs 0.03$)$, the test was not significant (Table 2).

\begin{tabular}{|c|c|c|c|c|}
\hline $\begin{array}{l}\text { Table } 3 \text { P } \\
\text { circumfe } \\
\text { (WHR) w } \\
\text { obese w } \\
\text { body ma }\end{array}$ & $\begin{array}{l}\text { tial co } \\
\text { nce (V } \\
\text { h lipid } \\
\text { nen aft } \\
\text { s index }\end{array}$ & $\begin{array}{l}\text { tion b } \\
\text { ind } w \\
\text { le in } \\
\text { djustn } \\
728 \text { ) }\end{array}$ & $\begin{array}{l}\text { ween } \\
\text { t-to-hi } \\
\text { erweig } \\
\text { nt for }\end{array}$ & $\begin{array}{l}\text { st } \\
\text { atio } \\
\text { and } \\
\text { and }\end{array}$ \\
\hline Variable & & & Wr & \\
\hline & $r$ & $\mathbf{P}$ & $r$ & $\mathbf{P}$ \\
\hline$\overline{\mathrm{TC}}$ & $0.10^{a}$ & 0.01 & $0.03^{a}$ & 0.4 \\
\hline TG & $0.14^{*}$ & 0.001 & $0.02^{*}$ & 0.5 \\
\hline $\mathrm{HDL}$ & -0.01 & 0.7 & 0.08 & 0.06 \\
\hline LDL & $0.03^{a}$ & 0.4 & $0.004^{a}$ & 0.9 \\
\hline
\end{tabular}

*Statistically significant $(\mathrm{P}<0.05)$ with z-test for Fisher's zeta transformation

${ }^{a}$ Difference between the 2 coefficients not significant $(P \geq 0.05)$ with $z$-test for Fisher's zeta transformation.
Partial correlation between WC and WHR with lipid profile after adjustment for age and BMI is presented in Table 3. Significant correlations were also found between WC index and TC $(P<0.01)$ and TG $(P<0.001)$ concentrations after adjustment for age and BMI. Although the partial correlation coefficient $(r)$ for $\mathrm{WC}$ with TC, TG and LDL-C was greater than the correlation coefficient for WHR with the same lipids, the z-test for Fisher's zeta transformation was only significant for TG $(P<0.05)$. There was no significant correlation between WHR and any of the variables (Table 3).

\section{Discussion}

We found that WC was strongly correlated with BMI. Similar findings have been observed in other studies $[17,18]$. A number of studies have also shown that high WC and BMI values precede the onset of morbidity due to diabetes and coronary heart disease $[19,20]$. However, 1 study found that both overall obesity and abdominal obesity were 
associated with the risk of CHD in women [21]. The utility of BMI and WC in predicting obesity-related health risk factors has been recognized by the National Heart, Lung, and Blood Institute of the National Institutes of Health, whose guidelines indicate that the health risk factors increase in a graded fashion when moving from the normal weight through the obese BMI categories, and that within each BMI category men and women with high $\mathrm{WC}$ values are at greater health risk than those with normal WC values [22]. Thus, it is assumed that $\mathrm{BMI}$ and $\mathrm{WC}$ have independent effects on obesity-related health risk factors. In fact, recent findings indicate that $\mathrm{WC}$ is a stronger marker of health risk than BMI [23].

The correlations observed between WC and lipid profile in the analysis changed after removing the total adiposity effect. The partial correlation and $z$-test for Fisher's zeta transformation suggested that WC had more effect on lipids/lipoproteins than WHR in women. A study in Danish men and women 35-65 years of age showed that more of the lipid variation was explained by overall obesity in men and more of the variation was explained by abdominal obesity in women [24]. Therefore, this issue needs to be further investigated.

After adjustment for BMI and age, WC remained significantly correlated with plasma TC and TG. Iranians are predisposed to raised serum lipid levels due to a diet rich in saturated fats and low physical activity $[25,26]$. Our study did not show strong significant correlations between $\mathrm{WC}$ and
LDL-C and HDL-C after adjustment for BMI and age.

The main significant abnormalities of lipids/lipoproteins related to central obesity were increased TC and TG for $\mathrm{WC}$ index. It seems that in women, WC was more associated with abnormal lipid/lipoprotein profiles than WHR. However, further investigation is needed on women in Sistan and Baluchestan to prevent and treat obesity because of its association with diabetes, coronary heart disease and other serious health conditions.

In conclusion, although several studies have analysed the association between serum lipids and anthropometric markers, some researchers, including ourselves, conclude that $\mathrm{WC}$ is a better anthropometric index of fat location for predicting lipid profile in overweight and obese adult women [5].

\section{Acknowledgements}

Our thanks go to all who participated actively in this project, especially the participants, physicians (Khosravi, Khaleghi Mogaddam, Porsaberi, Shideh, Karami,Sargolzaei and Masinaie) and experts (Porsharifi, Alavi, Mirshekar and Bahramian) who work in Zahedan Blood Transfusion Laboratory. We also thank Dr Saneii Mogaddam (head of Zahedan Blood Transfusion Laboratory), Dr Arab (Associate Professor, Zahedan University of Medical Sciences) and Dr Pourghasem (Assistant Professor, Tabriz University of Medical Sciences) for their invaluable help.

\section{References}

1. Klein $S$, Wadden $T$, Sugerman HJ. AGA technical review on obesity. Gastroenterology, 2002, 123:882-932.

2. Mohamadnejad $\mathrm{M}$ et al. Healthy ranges of serum alanine aminotransferase levels in Iranian blood donors. World journal of gastroenterology, 2003, 9:2322-4.

3. Howard BV. Obesity, lipoproteins, and heart disease. Proceedings of the Soci-

المجلة الصحية لشرق المتوسط، منظمة الصحة العالمية، المجلد الخامس عشر، العدد ع، 9 + • 
ety for Experimental Biology and Medicine, 1992, 200(2):202-5.

4. Abate $\mathrm{N}$ et al. Relationships of generalized and regional adiposity to insulin sensitivity in men. Journal of clinical investigation, 1995, 96(1):88-98.

5. Pouliot MC et al. Waist circumference and abdominal sagittal diameter: best simple anthropometric indexes of abdominal visceral adipose tissue accumulation and related cardiovascular risk in men and women. American journal of cardiology, 1994, 73(7):460-8.

6. Janssen I, Katzmarzyk PT, Ross R. Body mass index, waist circumference, and health risk: evidence in support of current National Institutes of Health guidelines. Archives of internal medicine, 2002, 162(18):2074-9.

7. Wang et al. Comparison of abdominal adiposity and overall obesity in predicting risk of type 2 diabetes among men. American journal of clinical nutrition, 2005, 81(3):555-63.

8. Esmaillzadeh A, Mirmiran P, Azizi F. Waist-to-hip ratio is a better screening measure for cardiovascular risk factors than other anthropometric indicators in tehranian adult men. International journal of obesity and related metabolic disorders, 2004, 28(10):1325-32.

9. Physical status: the use and interpretation of anthropometry. Report of a WHO Expert Committee. Geneva, World Health Organization, 1995 (Technical Report Series 854:1-452).

10. Okosun IS et al. Abdominal adiposity values associated with established body mass indexes in white, black and Hispanic Americans. A study from the Third National Health and Nutrition Examination Survey. International journal of obesity and related metabolic disorders, 2000 , 24(10):1279-85.
11. Huang $\mathrm{KC}$, et al. Four anthropometric indices and cardiovascular risk factors in Taiwan. International journal of obesity and related metabolic disorders, 2002, 26(8):1060-8.

12. Tanaka $\mathrm{K}$ et al. Obesity, body fat distribution and coronary atherosclerosis among Japanese men and women. International journal of obesity and related metabolic disorders, 2001, 25(2):191-7.

13. Musaiger AO, Al-Mannai MA. Weight, height, body mass index and prevalence of obesity among the adult population in Bahrain. Annals of human biology, 2001, 28(3):346-50.

14. Erem C et al. Prevalence of diabetes, obesity and hypertension in a Turkish population (Trabzon city). Diabetes research and clinical practice, 2001, 54(3):203-8.

15. Measuring obesity-classification and description of anthropometric data. Report on a WHO consultation on the epidemiology of Obesity, Warsaw, 21-23 October 1987. Copenhagen, World Health Organization Regional Office for Europe, Nutrition Unit, 1989 (EUR/ICP/ NUT 125).

16. Friedewald WT, Levy RI, Fredrickson DS. Estimation of the concentration of low density lipoprotein cholesterol in plasma, without use of the preparative ultracentrifuge. Clinical chemistry, 1972, 18(6):499-502

17. Grinker JA et al. Changes in patterns of fatness in adult men in relation to serum indices of cardiovascular risk: the Normative Aging Study. International journal of obesity and related metabolic disorders, 2000, 24(10):1369-78.

18. Ho SC et al. Association between simple anthropometric indices and cardiovascular risk factors. International journal of obesity and related metabolic disorders, 2001, 25(11):1689-97. 
19. Chan JM et al. Obesity, fat distribution, and weight gain as risk factors for clinical diabetes in men. Diabetes care, 1994, 17:961-9.

20. Hartz AJ et al. Relationship of obesity to diabetes: influence of obesity level and body fat distribution. Preventive medicine, 1983, 12(2):351-7.

21. Rexrode $\mathrm{KM}$ et al. Abdominal adiposity and coronary heart disease in women. Journal of the American Medical Association, 1998, 280(21):1843-8.

22. National Institutes of Health. Clinical guidelines on the identification, evaluation, and treatment of overweight and obesity in adults-the evidence report. Obesity research, 1998, 6(Suppl. 2):51S$209 S$.

23. Zhu $S$ et al. Waist circumference and obesity-associated risk factors among whites in the third National Health and $\mathrm{Nu}$ trition Examination Survey: clinical action thresholds. American journal of clinical nutrition, 2002, 76(4):743-9.

24. Heitmann BL. The variation in blood lipid levels described by various measures of overall and abdominal obesity in Danish men and women aged 35-65 years. European journal of clinical nutrition, 1992 , 46(8):597-605.

25. Sarraf-Zadegan N, Boshtam M, Rafiei M. Risk factors for coronary artery disease in Isfahan, Iran. European journal of public health, 1999, 9(1):20-6.

26. Azadbakht L, Mirmiran P, Azizi F. Predictors of cardiovascular risk factors in Tehranian adults: diet and lifestyle. Eastern Mediterranean health journal, 2006, 12(1/2):88-97.

\section{Global Database on Body Mass Index: an interactive surveillance tool for monitoring nutrition transition}

The global epidemic of overweight and obesity - "globesity" - is rapidly becoming a major public health problem in many parts of the world. Paradoxically coexisting with undernutrition in developing countries, the increasing prevalence of overweight and obesity is associated with many diet-related chronic diseases including diabetes mellitus, cardiovascular disease, stroke, hypertension and certain cancers.

The Global Database on Body Mass Index provides both national and sub-national adult underweight, overweight and obesity prevalence rates by country, year of survey and gender. The information is presented interactively as maps, tables, graphs and downloadable documents and can be accessed at: http://apps.who.int/bmi/index.jsp 